\title{
AN ALTERNATIVE READING OF AMOR TOWLES'S A GENTLEMAN IN MOSCOW
}

\author{
Rajendra Acharya*
}

\begin{abstract}
This paper explores Amor Towles's A Gentleman in Moscow (2016) as an Alternative Reading of Stalinian Era in terms of its reinterpretation of the Russian history and scrutinization of the historical documents. In doing so, this paper endeavors to study Amor Towles's A Gentleman in Moscow (2016), through the vantage point of Foucauldian discourse supported by Friedrich Nietzsche's notion of 'freewill', Catherine Gallaher and Stephen Greenblatt's notion of 'counter history. This Article further delves in to the official history and examines the power-politics of and behind the critique of Stalinian regime by observing the socio-cultural background of the author. The paper also offers more than one potential reading of Russian history and the novelist's social context in order to analyze the novel as a direct outcome of the clashing interpretations and concludes that, Towles, while crafting historical fiction, explicitly tantalizes Russian history, implicitly emphasizes American values and creates the new knowledge for the sake of subjugated through artistic discourse. Finally, the paper will demonstrate that the novelist invites the reader to concentrate and support the political power of marginalized group despite its absence in official history.
\end{abstract}

Keywords: Representation, Discourse, Freewill, Counter Culture,

\section{Introduction:}

A Gentleman in Moscow is a story of three generations that starts from the period of pre-Bolsevik revolution to the death of Stalin. The novel begins with the jury's decision of the protagonist Rostov's imprisonment in 1922, when he is sentenced to a life of house arrest in Moscow's Metropol hotel. Being a member of Russian nobility or the ex-aristocrats, which was going to be dissolved in communist government structure, Rostov was forced to change his luxurious life and the interests. Russia faced ups and downs to bring reformation as "Russia had suffered a world war, a civil war, two famines, and the so called Red terror" (17). In the very beginning, the protagonist has a difficult time, he feels restless, purposeless and spends the days by reading, drinking, roaming. Most of Rostov's possessions are confiscated and he is moved from his luxurious suite to the hotel, the place where he is condemned for life imprisonment.

Even, the new government appeals the poets of the existing time, exemplified by Mishka, to write poetry through the perspective of revolution. The act of power for the new knowledge extends to the field of literature along with politics.

Rostov's friend, Mishka comes to visit his imprisoned friend once, as a poet he is excited to see how communism will allow a new form of poetry. Mishka states the new concept of poetry as "in

* Teaching Assistant of Ratna Rajya Campus (Humanities Faculty: English Department), Tribhuvan University, Nepal. 
June they will gather to forgecnovaya poeziya, new poetry. One that is universal...one that doesn't hesitate and needn't know. One that has the human spirit as its subject and the future as its muse" (84). The new government attempts to make the poets of existing time to be the part of proletariat. The power, during the era twisted the aristocratic truth as per the need of time. The concept of 'defamiliarization', 'roughened language' and 'estrangement' were regarded as antirevolutionary. Rather than writing imaginary and metaphorical poems, the poets of the era were advised to pen simple poems in ordinary language for the common people.

When Rostov is house arrested by the new communist government, he faces difficult time during his imprisonment. His boredom ends when he befriends with Nina as she visits Rostov frequently and provides gifts on various occasions. Rostov loves wine but the new government bans all the alcoholic items which makes the protagonist unhappy and it is also the reason for his suicidal attempt. He is saved by Abram, who reminds Rostov of his orchards that no longer exists at present. Then the novel shifts to 1930s, where the historical incident of collectivization has been exposed against the peasants. Collectivization refers to the process where the farm land goes to the state from the individual for mass production and such task has been described by Towles as “it would be essential for the country's grain-producing regions to do their part-by meeting the increased demand for ....agricultural production" (128). During this time, many farmers are exiled by the contemporary government. Nina and her husband, who were working as bureaucrats during collectivization, went against the state policy as they take side of peasants. As a result, Nina and Leo have to face exile and their daughter Sofia is cared and up brought by Rostov.

In 1940s, during the time of WWII, Stalin plays an important role to defeat Hitler and end the long existing war. However, after the end of WWII, people counter Stalin for ruling the nation in hardline because of the evolving norms and values of the time. The novel ends with major characters like Rostov and Sofia's departure from the two and half decade's Stalinian policy as they choose to live on their own choice. Rostov, himself escapes the Metropol, having written letters of thanks to Viktor Stepanovich, who creates a false trail suggesting the Count has gone to Finland. However, with Sofia safely on her way to America, the Count goes to the countryside town where he grew up and spent his childhood. There, he also meets Anna Urbanova in an inn. Sofia' dream of leaving Russia for America and Rostov's dream of escaping imprisoned life stands as the symbolic departure from Stalinism

Since the paper aims to analyze the representation of Stalin's era in the novel, it brings theoretical insights from Foucault's notion of truth, power, language and knowledge. These basic parts of 'representation' together create discourse. The term discourse refers to a way of representing the knowledge about a particular subject matter at a specific historical moment. It also regulates the conduct of others by governing the consent of people. Similarly, the term 'representation' means the production of meaning and knowledge through discourse. As a system of representation, discourse is a way of representing the knowledge about particular subject matter at a specific historical context. With the construction of topic and the production of knowledge discourse regulates the conduct of others. What representation does is an attempt to produce a historical account of the formation of ideas and it also studies the way of certain spheres of society. Mainly, the research focuses on the analysis of emerging marginal citizens who transcends the conventional celebration of rulers. Yet observation is made in its depiction of discourse as the product of state power. 
As historical era transforms, so does discourse, there exists the possibility of the production of another truth. The paradigm shift of historical consciousness stands as the significant factor of new historicism because it disregards the notion of absolute truth. During the post-revolutionary Russia, the rising speed of Stalin's reign results in the mass murder, exile, censorship and a forced diaspora. The contemporary era particularly state is mentioned as malevolent toward mankind. This probability, in fact, increases with the novel's strange presentation of Russia as Towles remarks "Let us concede that . . Russia was unkind" (229). In order to avoid the state domination, finally the second generation character Sofia leaves Russia and flees to America. Learning through the action of Sofia, even the protagonist, the first generation character, escapes from being imprisoned.

Similarly, we can also consider the idea of paradigm shift in case of alcohol. The issue of 'wine' as an example from the novel, is an epitome of historical paradigm shift. Wine stood as a symbol of aristocracy before the revolution, however after the revolution it has been noted as counter to the revolution by the state. In order to change the bourgeoisie history, Stalin discontinues the aristocratic truth related to wine. The aristocratic concept of wine is counter for him as the novelist describes "A complaint was filed with comrade Tedorov, the commissar of Food, claiming that the existence of our wine list runs counter to the ideals of revolution" (142). Because of state power the imprisoned protagonist had to accept it, he had to change himself from the habit of drinking alcohol as he has been regulated by the official history The power of Stalin creates new knowledge regarding wine as alcohol banning is deeply practiced in the state, the meaning of wine has different meaning in two different historical circumstances.

On the one hand, the novel has been discussed as the radical American depiction of Russian history. While some others regard the novel to be the departure from American radicalism because the protagonist, being an aristocrat is given each facility in the imprisoned hotel. Being an American writer, a critic and a novelist, Towles satirizes Russian history particularly the policy led by Joseph Stalin. The characters in the novel live in despair and angst whether they are peasant, female, priest, actors, musicians or statesperson. According to James Millar, Stalin Era stands as the superiority of negative ideals over positive ones. As Stalin's era stands as the socialcontext of the novel, Miller depicts the period as an autocratic era because there was exile, mass murder, censorship, collectivization. Therefore, upon realizing these tasks of Stalin, Miller remarks "Soviet communism lapsed into autocracy under Josef Stalin, who was perhaps the most complete autocrat since Peter the Great" (8). This statement is in the line of revisionist historiography as the contemporary leader Stalin is elaborated as 'autocrat'. The citizens try to transform themselves, act on their own but finally have to face the reality of the time because of the regulation of Stalinian discourse.

Through the imprisonment of the protagonist, the writer conveys the pathetic condition of Russsian and through his escape Towles tries to depict their hope for freedom. In this context, this paper argues that the text stands as the 'reservoir' of representation. The term representation indicates the production of meaning and knowledge through discourse, which too goes on changing with the changing power, so does this novel where there exists the resistance of characters towards the then authority and the power. The incidents and the characterization in the novel where there is the maximum guidance of state stands as the matter of regulation as the people are state governed. Along with regulation and the governmentality, the challenge of 
characters to the state, on the other hand, can be regarded as breakthrough or 'disruption of historical truth' because of their move from devotion to the action.

The attempt of Leo and Nina to go against the state mechanism results in exile. Leo is banished from the country and Nina hides herself even in her own country. By acting on their own, as Leo and Nina assist farmers, the couple is establishing individual agency in front of state rules during the collectivization era. The state centric power, movement, revolutions, sometimes fail to change the social order. Through the character and their actions in the novel, there exists the controversy between the state and the citizens. Towles shows the people in margin possessing power analogous to the state despite the absent of such issues in real history. What Foucault suggests is that power can surpass the state and also he sees power as an everyday socialized phenomenon. The characters in the novel ultimately act on their own, despite the state prohibition, which can be interpreted by engaging with Nietzsche' notion of freewill and the conception of individual freedom. Nietzsche regards 'Will to Power' as 'a striving force for an increase of power . . . that all driving force is will to power, that there is no other physical, dynamic or psychic force except this" (366).

In case of freewill, Rostov's actions and Sofia who leaves for America are pivotal because they break the state rules for their freedom, hence the people in the margin are rewriting the historical truth. At the end of the novel, Rostov starts living by his own and challenges the Bishop, who is infact, the statesman as the novelist depicts "the count could see that the Bishop had undergone something of a transformation. He had suddenly lost his sense of self-superiority, as if all along it had been secured by his possession of these keys" (434). Bishop is the active member of the state and a manager of the hotel where Rostov has been imprisoned. There exists the regulation of discourse and the resistance of characters towards the then authority and power.

Discourse, in the novel, appears changing with the paradigm shift of the historical circumstances. Being imprisoned, the protagonist has to work in the hotel earlier but he also exposes some sort of power as Towles remarks "Picking up the ring, the count sorted through them until he found the smallest, then he unlocked Bishop's cabinets" (434). Thus, regarding Foucauldian notion of discourse there resides 'rupture' of power according to the shifting historical circumstances which can be applied in this scene of the novel because the once imprisoned man, Rostov challenges the prison officers and escapes to live a life of freedom. What Foucault suggests is that power can surpass the state and also he sees power as an everyday socialized phenomenon. This is a direct departure from the official history as the captivated person violates the rules and regulations.

Though the Russian history has designated discourse for the celebration of state policy, Towles shows another through the means of fiction. Thus official history of Russia becomes 'grand' narrative because only the greater self has been elaborated. There exists only interpretation but not presentation of dry facts in fiction. There is the impossibility of objective analysis because while narrating historical things, narrativization brings subjectivity of the historian. There is one truth of the nation in history but another side of truth for the novelist who vividly interprets the era as "At the same time, the most stalwart workers... artists faced tighter constraints on what they could or could not imagine; churches were shuttered, repurposed" (229). In this statement, unlike the realistic historical concept of 'autarkic' economy, we can observe the limitations the era was facing as workers and artists faced tighter constraints in this fiction.

Foucault's book The Order of things: An Archaeology of Human Sciences 
also presents key ideas regarding the new historicism because it explores the historic sense and roots of humanity. The central argument of the text is that different types of history create different types of knowledge "hence the possibility of writing a history of freedom and slavery based upon languages, or even a history of opinions, prejudices, superstitions, and beliefs of all kinds, since what is written on these subjects is always of less value as evidence than are the words themselves" (97). This is the act of representation which is distinct than normal ways of depicting the things. In the case of novel, the institution of Shalamov which controls literary art according to revolutionary ideals, stands as the creator of discourse against the aesthetics in art and literature. Foucault's representation is considered as the larger representation of history and the context.

The protagonist, Rostov is imprisoned in the hotel because he was supposed to have crafted the poem with revolutionary undertones. In this sense, Gregory Cowles reinterprets “Amor Towles's elegant tale of a Russian count confined for decades to house arrest at Metropol Hotel for writing a poem that displeased the Bolsheviks" (NY Times). Cowles's analysis exhibits that the contemporary government censors on the creative writing if that works against the spirit of the state. Foucault's representation covers the spirit of the holistic and heterogeneous era related to history as "Indeed, more so than the meaning of representations, Foucault was concerned with the representation of knowledge, and the context in which such representations are given form, meaning, and, ultimately, applied" (42). While representing the society and the broader context, representation, on the one hand discusses power as the source of hegemony because the privileged groups maintain authority over the powerless ones. There resides hegemony in the novel because the dominant group of the state hegemonizes Rostov for life imprisonment and artists, actors, poets are also unable to craft their vision. The national agenda is maintained and regulated by the dominant culture in a univocal manner.

On the one hand, people are regulated by the discourse, while on the other, they can change, transform and resist the existing discourse. Not only state and powerful one possesses the authority to run the state but a normal human can also counter the government policy if that is against the spirit of humanity. Foucault's 'death of subject' is viewed by Raymond Caldwell in new light, "agency is related to new, more positive and potentially emancipatory discourses that redefines the relationship between agency and change, resistance and power in organizations and society" (1). As elaborated by Caldwell, agency is the source of power, knowledge, resistance and creative ideas. Thus death of subject is a metaphor which can also indicate the death of preestablished belief system. Though characters were unable to use their right of freedom of expression before, but now they can express their view freely. The protagonist exclaims that he is in quest of democracy like that of America to Anna, when she asks Rostov what his intention really is:

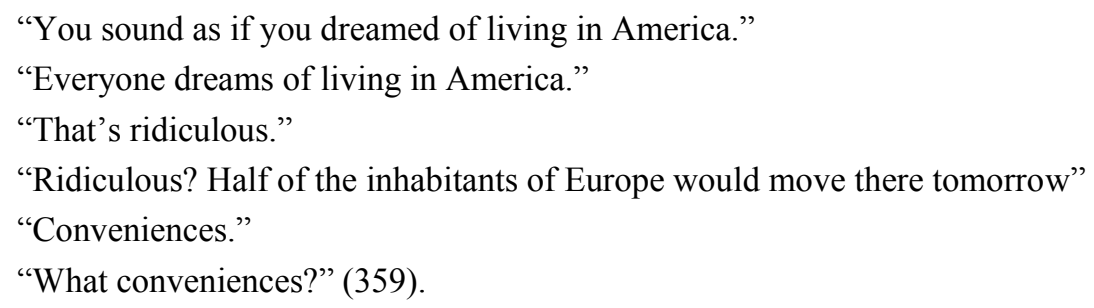


Hence, the way the protagonist talks foreshadows the freedom of people who seek to enjoy their life according to their will. The characters like Rostov, Sofia, Mishka being regulated by discourse are able to transform themselves, therefore death of agency here means birth of new agency. By showing the change of the characters, Towles depicts the contemporary Russia as unkind. As a pioneer of new historicist movement, Foucault supports the exclusive group of the society opposed to mainstream. Towles employs similar trends because he highlights the excluded rather than the people in the top. Foucault believes solidly in human freedom. Subjugated and forbidden issues are entertained by both Foucault and Towles.

At any given moment, it is the manifestation of a thousand transitions. Our faculties wax and wane, our experiences accumulate, and our opinions evolve-if not glacially, then at least gradually. Such that the events of an average day are as likely to transform who we are as a pinch of pepper is to transform a stew. (402)

The punishment to marginal people becomes not the solution but the approaching eradication of authority as Foucault's book Discipline and Punishment indicates "it is the certainty of being punished and not the horrifying spectacle of public punishment that must discourage crime; the exemplary mechanics of punishment changes its mechanism" (9). Discipline can also be regarded as the violent exercise of power often regulated by the people in power, it is the way of creating subjectivity, and it is the technique of producing self that is forcefully guided by state mechanism. People are regulated and hegemonized by the disciplinary mechanisms and the institutions that form discourses. The citizens in Russia are controlled, disciplined and punished by the state for not applying the state policies mainly before WWII.

In their text, Practicing New Historicism, Catherine Gallaher and Stephen Greenblatt, exhibits the evolving counter cultural practice within the New Historicism. It is a form of theory which understands literature as the epitome and critique of cultural context. The writers elaborate counter history as "counter history opposes itself not only to dominant narratives, but also to prevailing modes of historical thought and methods of research; hence, when successful, it ceases to be "counter" (52). This statement makes clear that counter history opposes the existing homogenous belief system and counters the prevalent modes of historical thought. Regarding the significance of counter history the writers also opine that it disrupts the historical anecdotes and the big narratives as they remark "new historicists linked anecdotes to the disruption of history as usual, not to its practice: the undisciplined anecdote appealed to those of us who wanted to interrupt the Big Stories" (51). Instead of abstract ideas, the materialist thinkers, Greenblatt and Gallaher believe in concrete issues and pinpoint the lapses of abstraction-linked official history.

As fiction or any narrative can counterattack history, A Gentleman in Moscow counters the official histories charging them as big narratives. Towles creates counter history of Russia through this novel despite the concept of official history which regards the post revolution era as progressive. The way in which the novel counterattacks the official history can be interpreted as the example of counterculture. Though state regards the nation in the path of prosperity after the revolution, the novel stands counter to such official ideas as it counterattacks the official truth from the beginning phase of post-revolutionary era. This idea of counterculture has been remarked by the novel in the following light:

Refined ingredients became as scarce in Moscow as butterflies at sea. The Metropol's larder was depleted bushel by bushel, pound by pound, dash by dash, and its chef was 
left to meet the expectations of his audience with cornmeal, cauliflower, and cabbagethat is to say, with whatever he could get his hands on. (26)

These lines suggest Towles's symbolic challenge of Stalinist Russia. It is in the line of personal freedom rather than the state centric ideas. The history of the nation shows that all the people are equal in Russia no matter how much rich and poor they were in the past. However, it was not so, as depicted in the narratives of the novel. Reading the novel from the perspective of new historicism, Rubin valorizes the counter action of the protagonist as he disregards the law of the state. Rubin, upon realizing the protagonist, claims the novel as the symbolic challenge to Stalinist Russia as "We watch him, from 1922 to 1954, dealing at first with the abrupt change in his own circumstances, and then with the increasingly inhumane consequences of the Utopian project going on outside the confines of the hotel" (142). The novel critiques upon the lost past of aristocrats who are now on the verge of losing their earlier ideals.

\section{Conclusion}

In the end, spending the large part of novel in critiquing Stalin, adhering the characters in the margin, activating their mind for American dream of freedom, happiness and liberation and criticizing Russian history in A Gentleman in Moscow, Towles establishes alternative marginal history through this fiction. He replaces the role and identity of Stalin in order to celebrate the freedom of the people in the margin. The novel represents the Stalinist era and critiques upon it from the perspective of margin in relation with history, power, truth, knowledge, freewill, counterculture, biopower, superman, governmentality and discourse. The way, Towles, arranges America for the relief of the characters conveys official history of Russia as different as the will of marginalized group. This notion makes him establishing the alternative history through the means of fiction. Offering freewill, counterculture and discourse as a remedy to the contemporary history of Stalinian era, the paper represents Russian marginal by making them acting on their own, and also it critiques the Stalinian ideals by counterattacking the official history.

\section{Works Cited}

Caldwell, Raymond. “Agency and Change: Re-evaluating Foucault's Legacy.” Birbeck College, University of London, UK, 2007. Volume 14(6): 000-000 ISSN 1350-5084, p.1.

Catherine Gallaher and Stephen Greenblatt. Practicing New Historicism. University of Chicago Press, 2000, pp. 51-52.

Engels, Frederick. Manifesto of the communist Party. FOREIGN LANGUAGES PRESS PEKING, 1970, p. 13. 
Foucault, Michael. The Order of Things: An Archaeology of the Human Sciences. Taylor and Francis Group. 1966, P. 42- 365.

Foucault, Michael. The Power of Truth edited by Sylvere Lotringer \& Lysa Hochroth. Columbia University New York, 1997, p. 8.

Millar. James R. Encyclopedia of Russian history. Library of Congress. 2004, pp. 4-379.

Nietzsche, Friedrich. The Will to Power. Translated by Walter Kaufmann and R. J. Hollingdale, Vantage Books, 1968, pp. 13-366.

Schlesinger, Rudolf. "Recent Soviet HistoriographyII". Soviet Studies. Published by: Taylor \& Francis, Ltd. Vol. 2, No. 1.https://www.jstor.org/stable/148681, p, 13.

Towles Amor. A Gentleman in Moscow. Penguin, Random House, 2016. 